\title{
Immunomodulatory Effects of Propolis and its Components on Basic Immune Cell Functions
}

\author{
K. WOLSKA*, A. GÓRSKA, K. ANTOSIK AND K. ŁUGOWSKA \\ Department of Dietetics and Food Assessment, Institute of Health Sciences, University of Natural Sciences and Humanities, \\ Prusa 14, 08-110 Siedlce, Poland
}

Wolska et al.: Immunomodulatory action of propolis and its components

\begin{abstract}
Propolis (bee glue) is a resinous hive product collected by honey bees from many plant sources in temperate and tropical climates. It's fairly complex chemical composition includes polyphenols, phenolic aldehydes, sequiterpenes, quinins, coumarins, amino acids, steroids and inorganic compounds. The contents of propolis depended especially on its location and plant sources. Consequently, the biological activity of propolis gathered from different phytogeographical areas can vary. Propolis is known to have a broad spectrum of biological properties, including antimicrobial, antioxidant, antiinflammatory, antiallergic, dermatoprotective, laxative, antidiabetic, antitumor and immunomodulatory activity. The immunomodulatory activity of propolis has been well-researched. This activity is attributed to flavonoids and some phenolic acids, mainly caffeic acid (cinnamic acid) phenethyl esters and artepillin C (3,5-diprenyl-4-hydroxycinnamic acid). Propolis and these components exhibited immunomodulatory effects on a wide spectrum of immune cells, including cells of lymphoid or monocytic lineages, mediated by the extracellular signal-regulated kinase 2 and mitogenactivated protein-kinase signalling pathway and by eukaryotic transcription factors: nuclear factor of activated $T$ cells and nuclear factor-kappa $B$. In vitro and in vivo assays have demonstrated that propolis activated monocytes/macrophages and neutrophils, increasing their microbicidal activity. It enhanced the lytic activity of natural killer cells against tumour cells. It also exhibited antiallergic effects, in part by inhibiting degranulation of mast cells or basophils. Propolis stimulated greater antibody production, suggesting that it could be used as an adjuvant in vaccines. Its inhibitory effects on lymphoproliferation might be linked to its antiinflammatory properties. However, this effect appeared to occur in the presence of high concentrations of propolis, while at low concentrations the effect is reversed, causing stimulation of lymphocyte proliferation.
\end{abstract}

Key words: Propolis, components of propolis, immunomodulatory action, immune cells, antiinflammatory action

Propolis is a product of the vital activity of the honey bee Apis mellifera. Bees produce propolis by mixing substances gathered from budding plants, flower buds and resinous exudates. They thus produce a material suitable for closing gaps, embalming dead insects within the beehive and protection from invasion by microorganisms and insects. This activity of propolis results from its composition. Raw propolis is typically composed of $50 \%$ plant resins, $30 \%$ waxes, $10 \%$ essential and aromatic oils, $5 \%$ pollens and $5 \%$ other organic substances ${ }^{[1]}$.

Propolis possessed a variety of biological and pharmacological effects, such as antibacterial, antioxidant, antitumour, antiinflammatory and immunomodulatory. However, propolis could not be used as a raw material, so it must be purified by

*Address for correspondence E-mail: kwolska@uph.edu.pl

July-August 2019 extraction to remove the inert material and preserve the polyphenolic fraction, which is primarily responsible for its activity ${ }^{[1,2]}$. Generally, ethanol is the best solvent for propolis preparation, but other solvents such as ethyl ether, water, methanol and chloroform could also be used for extraction and identification of propolis constituents ${ }^{[3]}$. More than 300 different compounds have been identified in propolis, including phenols, tannins, polysaccharides, terpenes, aliphatic acids, esters, aromatic acids, fatty acids, aldehydes, amino

This is an open access article distributed under the terms of the Creative Commons Attribution-NonCommercial-ShareAlike 3.0 License, which allows others to remix, tweak, and build upon the work non-commercially, as long as the author is credited and the new creations are licensed under the identical terms

Accepted 02 May 2019

Revised 10 June 2018

Received 13 September 2017

Indian J Pharm Sci 2019;81(4):575-588 
acids, ketones, chalcones, dihydrochalcones, vitamins and inorganic substances. Among these, flavonoids and phenolic acids are of greatest interest to researchers ${ }^{[3,4]}$.

The chemical characteristics of propolis have been found to be linked to the diversity of geographical location, plant sources and bee species. Poplar (Populus nigra L. and P. alba L) is common in the temperate zone, especially in Europe, and gives its name to a type of propolis that is rich in flavonoids and phenylpropanoids. However, flavonoids are not restricted to poplar; furthermore, in areas where poplars are not native plants, such as Australia and the equatorial regions of South America, bees would seek other plants to produce propolis, which contain flavonoids of poplar-type propolis ${ }^{[5]}$. The characteristic constituents of propolis of temperate regions are flavonoids without B-ring substituents, such as chrysin, galangin, pinocembrin, pinobanksin, and aromatic acids and their esters. Caffeic acid phenethyl ester (CAPE) is a major constituent of temperate propolis with broad biological activity. Parts of the world outside of Europe in which propolis exhibits chemical profiles similar to those of poplar-type propolis included $\mathrm{China}^{[6]}$, North America $^{[3]}$, various regions of Taiwan ${ }^{[7,8]}$, New Zealand $^{[9]}$ and Africa ${ }^{[10]}$.

Significant amounts of phenolic glycerides (23.1 mg/g), i.e. dicoumaroyl acetyl glycerol, diferuloyl acetyl glycerol, feruloyl coumaroyl acetyl glycerol, and caffeoyl coumaroyl acetyl glycerol were isolated by Popravko et al. ${ }^{[11]}$ from North-Russian propolis and the exudate of $P$. tremula was found to be their plant source. However, the primary plant source of propolis in Russia is Betula verrucosa Ehrh., and its main biologically active substances are flavones and flavonols (but not the same as those in poplar propolis) $)^{[12]}$.

The propolis of tropical regions, especially the green propolis of southern Brazil, which has Baccharis dracunculifolia as its primary plant source, contains dihydrocinnamic acid, $p$-coumaric acid, prenyland diprenyl- $p$-coumaric acids and flavonoids ${ }^{[13]}$. Typical constituents of this propolis are kaempferide (3,5,7-trihydroxy-4'-methoxyflavone) and cinnamic acid derivatives, $p$-coumaric acid (4-hydroxycinnamic acid), artepillin $\mathrm{C}$ (3,5-diprenyl-4-hydroxycinnamic acid), baccharin (3-prenyl-4-(dihydrocinnamoyloxy)cinnamic acid) and drupanin (3-prenyl-4hydroxycinnamic acid $)^{[14,15]}$. The other common-type of propolis in the tropical region is Brazilian red propolis (BRP), which is collected in northern Brazil from the surface of Dalbergia ecastophyllum. This propolis is rich in flavonoids, mainly liquiritigenin, daidzein, dalbergin, isoliquiritigenin, formononetin and biochanin A. Three of these (daidzein, formononetin and biochanin A) are isoflavonoids ${ }^{[16]}$. Propolis is produced by the honey bee Apis mellifera, which is wide spread in Europe, the Ural mountains, Africa, and Asia. The European honey bee A. mellifera is the most common species of honey bee. Brazilian green and red propolis originate from the Africanized A. mellifera ${ }^{[4]}$.

The immunomodulatory activity of propolis (fig. 1) and its antiinflammmatory properties have been particularly well researched. The eukaryotic transcription factors nuclear factor of activated T cells (NFAT) and nuclear factor- $\kappa-\mathrm{B}(\mathrm{NF}-\kappa \mathrm{B})$ play a central role in immune and inflammatory responses. Activation of NFAT and $\mathrm{NF}-\kappa \mathrm{B}$ proteins is induced by many factors, such as inflammatory cytokines (interleukine-1, IL-1 and tumour necrosis factor, TNF), bacterial products, and oxidative stress. These two major transcription factors are involved in expression of the IL-2 and IL-2R genes, which are necessary for $\mathrm{T}$ cell activation and proliferation $^{[17]}$. The immunomodulatory properties of propolis are contributed by its flavonoids and phenolic $\operatorname{acids}^{[18-21]}$. Yuan et al. ${ }^{[21]}$ reported that these phenolic compounds might be important components activating innate and adaptive immune cells. Although the precise mechanism of action of propolis on immune cells remains unknown, it is possible that the flavonoids stimulate macrophages and lymphocytes to produce IL-1 and IL-2, respectively, which have mitogenic action on B and T lymphocytes ${ }^{[22]}$. For example, artepillin C, found in large quantities in green propolis samples, acts on macrophages by stimulating the production of IL12, which stimulates the Th1 lymphocyte response and inhibits the Th2 response. Other phenolic compounds found in the propolis samples, such as cinnamic acid, also induce the production and release of cytokines, such as IL-1, IL- 6 and IL- 8 by activated macrophages, stimulating antibody production by B lymphocytes and acting chemotactically on neutrophils. Such mechanisms may explain the increment in innate and adaptive (humoral and cellular) immunity ${ }^{[22]}$.

Some authors ${ }^{[23,24]}$ suggested that the immunomodulatory activity of propolis is strictly dependent on its concentration. A low concentration of propolis has a stimulating effect on the cellular immune response, whereas a high propolis concentration exerts an inhibitory effect. In particular, flavonoids have an immunosuppressive effect in the lymphoproliferative 


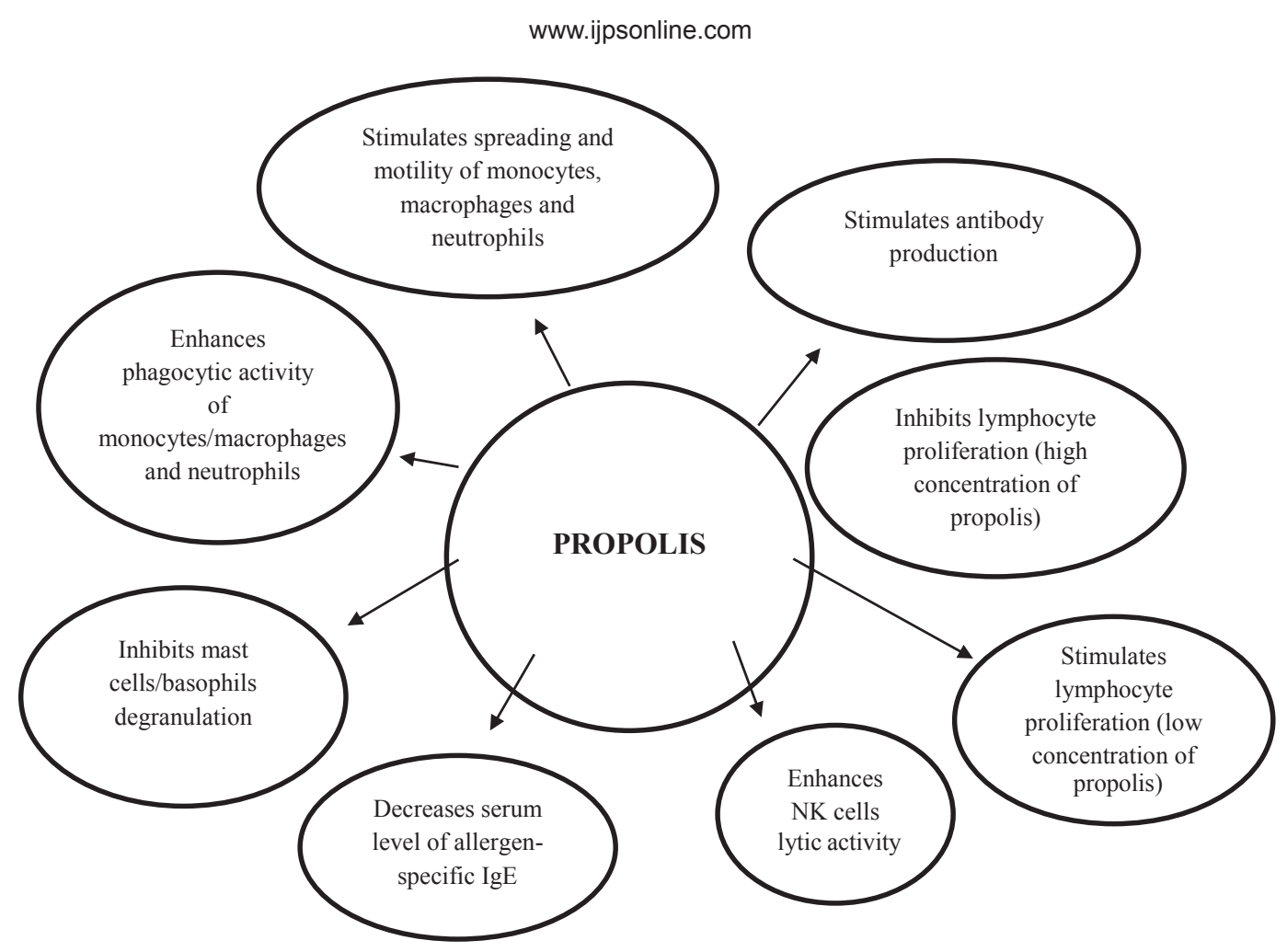

Fig. 1: Propolis immunomodulatory action

response. These natural components block activation of DNA binding of nuclear factors (NFAT and $\mathrm{NF}-\kappa \mathrm{B})^{[17]}$.

\section{Immunomodulatory effects on neutrophils, monocytes and macrophages:}

Propolis and some of its constituents, such as CAPE, cinnamic acids, and artepillin $\mathrm{C}$, affect nonspecific (innate) immunity via modulation of neutrophile and monocytes/macrophages activity ${ }^{[25-28]}$. The neutrophil polymorphonuclear leukocytes are an important component in nonspecific immunity and are the main phagocytic cells found in the peripheral blood ${ }^{[24,29]}$. Monocytes/macrophages are the other effector cells of the immune system that protect against microbial infection. Macrophages are mononuclear phagocytic cells derived from peripheral blood monocytes and are resident in most tissues. They act as a bridge between the innate and the adaptive immune systems by differentiating into cells to exert diverse functions after being activated by various stimuli, such as interferon- $\gamma$ (IFN- $\gamma$ ). Monocytes/macrophages have three important functions, phagocytosis, antigen presentation to effective T cells, and synthesis of various inflammatory mediators $^{[30,31]}$.

When bacteria as an antigen enter the body they will be eliminated by neutrophils and monocytes/ macrophages. Phagocytosis is the main mechanism for destruction of microorganisms within phagocytic cells in the innate immune system. This complex process has the following phases; phagocyte chemotaxis, adhesion of microorganisms to the surface of phagocytes, endocytosis, and killing of the microorganisms. Microbes are destroyed within phagocytic cells through two mechanisms; one oxygen-dependent (production of reactive oxygen intermediates (ROI) and nitrogen intermediates) and the other oxygen-independent (including the release of lysosomal enzymes such as lysozyme and proteinases). It should be added that immune phagocytosis with non-specific opsonins, e.g. complement components (C3b) or specific opsonins (antibodies IgG) is more efficient than what is known as non-immune phagocytosis without opsonins ${ }^{[24,29,30]}$. The secretion of ROI is the main mechanism for the destruction of microorganisms. However, ROI may also destroy important biomolecules and are involved in tissue injury associated with inflammatory disease $^{[32]}$. As professional phagocytes, neutrophils are responsible for killing extracellular microorganisms, whereas monocytes/macrophages destroy cells infected with pathogens, including intracellular bacteria (e.g. Salmonella), yeasts and parasites.

Several studies have demonstrated that the phagocytic activity of these cells and their motility can be enhanced 
by immunomodulatory substances such as propolis and its components (Table 1). As early as the 1970s, Scheller et al. ${ }^{[33]}$ suggested that immunostimulatory activity of propolis is associated with macrophage activation and enhancement of macrophage phagocytic capacity. Orsi et al.$^{[34]}$ demonstrated that after propolis treatment ( 2.5 and $5 \mathrm{mg} / \mathrm{kg}$ ) of mice for 3 consecutive days, peritoneal macrophages were activated in vitro with IFN- $\gamma$, and production of $\mathrm{H}_{2} \mathrm{O}_{2}$ and $\mathrm{NO}$ was increased in comparison to non-activated cells (control). This suggested that propolis treatment leads macrophages to a higher responsiveness to stimuli such as IFN- $\gamma$. However, depending on its concentration $(10,30$ and $60 \mathrm{mg} / \mathrm{kg})$, macrophages from propolistreated animals, stimulated in vitro with IFN- $\gamma$, inhibitied $\mathrm{H}_{2} \mathrm{O}_{2}$ and $\mathrm{NO}$ generation.

Further research by the same author ${ }^{[35]}$ showed that both Brazilian and Bulgarian propolis samples increased the bactericidal activity of macrophages against Salmonella typhimurium - the causative agent of typhoid fever in humans, depending on its concentration $(3,10,30$ and $100 \mu \mathrm{g} / \mathrm{ml})$. However, no differences were seen between these samples, although they were produced in different geographic regions. The data confirmed previous research findings that the bactericidal activity of macrophages, with different macrophage/bacteria ratios and different propolis concentrations, might have occurred through oxygen and nitrogen intermediates.

Peritoneal macrophages from Sprague Dawley rats infected with Staphylococcus aureus and treated with propolis of Trigona spp. exhibited improved phagocytosis. A significant increase in phagocytic activity (number of macrophages with phagocytic latex particles per one hundred macrophages) was observed with different concentrations of propolis $(0.16-80.7 \%$; $0.46-88.4 \% ; 1.44-90.1 \%)$ similar to that observed for CAPE (0.5-87.2\%). This study also found that propolis increased NO production in macrophages ${ }^{[36]}$. The compound in propolis of Trigona sp. from Indonesia, which activated the macrophages was probably limonene ${ }^{[37]}$.

Similarly, Possamai et al. ${ }^{[38]}$ found that mononuclear phagocytes in human blood exposed to $50 \mu \mathrm{g} / \mathrm{ml}$ of Brazilian propolis adsorbed onto polyethylene glycol microspheres presented high levels of superoxide release, phagocytosis of pathogenic yeast Candida albicans, and microbicidal activity. In this study the main chemical constituents of this propolis were tannins, phenols, flavonoids and xanthones, and to a lesser degree, flavanones and resins. The study by Murad et al. ${ }^{[39]}$ suggested an increase in the fungicidal activity of macrophages by propolis stimulation, independently of its geographic origin. Peritoneal macrophages from $\mathrm{BALB} / \mathrm{C}$ mice were stimulated with Brazilian or Bulgarian propolis and subsequently challenged with Paracoccidioides brasiliensis, which causes paracoccidioidomycosis, the most important systemic mycosis in Latin America.

Dantas et $a l .{ }^{[40]}$ investigated the effects of Bulgarian propolis (25 and $50 \mathrm{mg} / \mathrm{kg}$ ) in an experimental model of Trypanosoma cruzi-infected Swiss mice, verifying that this bee product led to a decrease in parasitaemia and showed no hepatic or renal toxic effect. Syamsudin et al..$^{[41]}$ demonstrated that Indonesian propolis extract displayed more immunostimulatory activity as shown by the increase in IgG against surface antigens of Plasmodium berghei. The antiplasmodial activity of propolis hydroalcoholic solution (PHS) was due to the increased immunity in the mice, owing to which they lived longer. However, PHS (25, 50 and $100 \mathrm{mg} / \mathrm{kg}$ ) showed weaker antiplasmodial activity than chloroquine $(10 \mathrm{mg} / \mathrm{kg})$.

Other authors $^{[24]}$ demonstrated that administration of Brazilian green propolis promoted phagocytosis of chicken red blood cells by peritoneal macrophages in

TABLE 1: EFFECT OF PROPOLIS ON PHAGOCYTIC ACTIVITY OF MACROPHAGES AND NEUTROPHILS

\begin{tabular}{|c|c|c|c|c|c|}
\hline Cells & Effect & Propolis dose & In vivo/in vitro & $\begin{array}{l}\text { Main groups or active } \\
\text { components }\end{array}$ & Reference \\
\hline \multirow[t]{2}{*}{ Macrophages } & $1 \uparrow$ & $0.46 \%{ }^{2} \mathrm{bw}$ & $\begin{array}{l}\text { In vivo male rats } \\
\text { Spraque Dowley }\end{array}$ & $\begin{array}{c}\text { Limonene,1-heptacosanol, } \\
\text { heptacosane, } \\
\text { 1-hexadecanol, } \\
\text { dioctyladipote, hexadecane }\end{array}$ & 37 \\
\hline & $\uparrow$ & $157.4 \mathrm{mg} / \mathrm{kg}$ bw & $\begin{array}{l}\text { In vivo aged } \\
\text { Kunning mice }\end{array}$ & $\begin{array}{l}\text { Polyphenols, flavonoids, } \\
\text { cinnamic acid, artepillin C }\end{array}$ & 24 \\
\hline Neutrophils & $\uparrow$ & $40 \mu \mathrm{g}$ & $\begin{array}{l}\text { In vitro } \\
{ }^{3} \text { neutrophils }\end{array}$ & Pinocembrin, galangin & 42 \\
\hline
\end{tabular}

${ }_{1 \uparrow} \uparrow$ - stimulant action; ${ }^{2} \mathrm{bw}$ - body weight; ${ }^{3}$ neutrophils - nutrophils isolated from periphenal venous blood of adult male 
aged mice at a dose of $157.4 \mathrm{mg} / \mathrm{kg}$, and significantly increased the phagocytic index (the average number of chicken red blood cells phagocytized per peritoneal macrophage cell) at $352.9 \mathrm{mg} / \mathrm{kg}(83.20 \pm 10.25$ and $2.53 \pm 0.87 \%$, respectively) in comparison to the control group (without propolis; $70.71 \pm 13.70$ and $1.80 \pm 0.48 \%$, respectively). They concluded that artepillin $\mathrm{C}$ might be one of the most important constituents of Brazilian green propolis responsible for activating macrophage phagocytosis. The content of this component in the analysed sample of propolis was $23 \mathrm{mg} / \mathrm{g}$.

The immunomodulatory activity of partially purified propolis extracts (PPPEs) from northern Argentina and flavonoids (galangin and pinocembrin) was investigated by testing their in vitro effect on neutrophil chemotaxis and phagocytic activity ${ }^{[42]}$. PPPEs were more effective (about 45 and $50 \%$ for a concentration of $40 \mu \mathrm{g}$ of PPPEs/ml of active substance) as chemotactic agents than galangin and pinocembrin (around 20 and $25 \%$, respectively) and showed higher neutrophil phagocytic activity $(270 \pm 10 \%)$ than galangin and pinocembrin ( $180 \pm 10$ and $135 \pm 9 \%$, respectively). The greater effect of PPPEs could be attributed to a synergistic effect among components of PPPEs. The results of this study indicated that PPPEs and flavonoids (galangin and pinocembrin) stimulate neutrophil chemotaxis and phagocytic activity. A study by Rindt et al. ${ }^{[43]}$ also confirmed the effect of propolis from Romania on the phagocytic activity of neutrophils. They investigated the immunological activity of ethanol extracts of propolis on in vitro phagocytic activity of blood leukocytes from cows with subclinical mastitis using the carbon particle inclusion test. Phagocytosis in the control without propolis was significantly decreased as compared to the test sample, especially during the second half of the incubation period $(\mathrm{p}<0.001)$.

A study by Fischer et al. ${ }^{[44]}$ showed that the polyphenol compounds extracted from Brazilian green propolis could act as vaccine adjuvants, improving innate and adaptive (humoral and cellular) immune responses in mice inoculated with inactivated vaccines. However, propolis flavonoids do not easily dissolve in water. Therefore, when propolis flavonoids are encapsulated with liposome, not only their solubility increased, but also the immunological adjuvant is synergistic. The results showed that propolis flavonoids liposome can significantly enhance the phagocytic function of macrophages in vitro and the release of IL- $1 \beta$, IL-6, and IFN- $\gamma$. Other research has demonstrated that propolis flavonoids liposome, like pathogen-associated molecular patterns, can be recognized by the innate immune system through interaction with macrophages, and the results could be linked to the activation of tolllike receptor (TLR) signal pathways ${ }^{[28]}$.

Neutrophils, monocytes and macrophages additionally play an important role in inflammation. During inflammation, upon stimulation by LPS from Gramnegative bacteria and IFN- $\gamma$ or TNF- $\alpha$ from host immune cells, neutrophils or monocytes/macrophages release large amounts of reactive oxygen species (ROS) and nitrogen species (RNS), nitric oxide (NO), and numerous cytokines, and generate important inflammatory mediators such as prostaglandins (PG) and leukotrienes ${ }^{[45]}$. Overexpression of these mediators causes pathological acute or chronic inflammatory responses $^{[31]}$. Numerous findings have shown antioxidant and antiinflammatory effects of propolis extract $^{[15,18,25,45-48]}$. The biologically active molecules in propolis are phenolic acids and flavonoids, which act as scavengers of free radicals and inhibitors of NO and inflammatory cytokine production by monocytes/ macrophages and neutrophils.

Significant linear correlations were observed between total phenolic content of propolis from different regions of Poland and antiradical activity measured using 1,1-diphenyl-2-picrylhydrazyl radical (DPPH•; 1.92-2.69 $\mathrm{mM} \mathrm{TE/g}$ ) and 2,2-azinobis (3-ethylbenzothiazoline-6-sulfonic acid (ABTS •+; 3.96-4.98 $\mathrm{mM} \mathrm{TE} / \mathrm{g})^{[49]}$. The dominant phenolic acid was $p$-coumaric acid, while chrysin and galangin were dominant among flavonoids. Similarly, Brazilian green propolis and two of its components, kaempferide and artepillin $\mathrm{C}$, exerted strong free-radical scavenging activity based on reduction of DPPH $\bullet$ and ABTS $\bullet+[15,50]$. The effect of Brazilian and Polish propolis in ROS scavenging has also been determined by a chemiluminescence assay. ROS and RNS release by PMA-activated J774A.1 murine macrophage cells was significantly inhibited by EEP-B in a dose-dependent manner ${ }^{[51]}$. Others have demonstrated that extracts of Polish and Brazilian green propolis and kaempferide decrease the chemiluminescence produced by stimulated neutrophils ${ }^{[45,47,48]}$.

Błońska et al. ${ }^{[46]}$ observed inhibition of NO synthesis and iNOS mRNA expression in LPS-stimulated J774A.1 macrophages by Polish propolis extract and its phenolic components: chrysin, galangin, kaempferol, and quercetin. Similarly, data obtained by Szliszka et al. ${ }^{[51]}$ have confirmed the effect of Brazilian 
propolis on NO generation in J774A.1 cells stimulated with LPS+IFN- $\gamma$. Another study ${ }^{[52]}$ demonstrated that artepillin $\mathrm{C}$ decreases $\mathrm{NO}$ concentration and has an inhibitory effect on $\mathrm{PGE}_{2}$ by modulating $\mathrm{NF}-\kappa \mathrm{B}$ in RAW264.7 murine macrophage lines incubated with LPS. In an experiment by Hu et al. ${ }^{[53]}$, treatment of ICR mice and Wistar rats with ethanol (EEP) and water (WEP) propolis extracts inhibited the increase of $\mathrm{PGE}_{2}$ and also had a significant inhibitory effect on NO in carrageenan-induced pleurisy.

According to Mirzoeva and Calder ${ }^{[54]}$ dietary propolis markedly affected the inflammatory response. Mice fed a diet containing $0.2 \%$ propolis produced decreased amounts of $\mathrm{LTB}_{4}, \mathrm{LTC}_{4}$ and $\mathrm{PGE}_{2}$ in response to inflammatory challenge in vivo. Some substances found in propolis, such as caffeic acid, quercetin, naringenin, and caffeic acid phenethyl ester, contribute to the suppression of PG and leukotriene synthesis by peritoneal macrophages stimulated with A23187 or LPS. Similarly, the antiinflammatory activity observed in green propolis seems to be due to the presence of prenylated flavonoids and cinnamic acid. These compounds exhibited inhibitory activity against cyclooxygenase (known as PG-endoperoxide synthase) and lipoxygenase, which produces several, chemically different leukotrienes ${ }^{[45]}$.

Cytokines secreted by immune cells play an important role in immune and inflammatory responses in vivo. Many cytokines secreted by macrophages were analysed by Szliszka et al. ${ }^{[51]}$, who demonstrated that Brazilian green propolis significantly downregulated the production of IL- $1 \alpha$, IL-1 $\beta$, IL-6, IL-12p40 and TNF- $\alpha$ in LPS + IFN- $\gamma$-treated J774A.1 cells. The secretion of interleukins IL-4 and IL-13 and colonystimulating factors G-CSF, and GM-CSF were also reduced by propolis, whereas the concentrations of IL-3, IL-5, IL-9, IL-10, IL-17 and IFN- $\gamma$ were only slightly affected by incubation with EEP-B, or not at all. No significant increase in serum IL- $1 \beta$, IFN- $\gamma$ and IL-4 levels was found after administration of Brazilian green propolis at varying doses (83.3, 157.4 and $352.9 \mathrm{mg} / \mathrm{kg}$ ) to aged mice ${ }^{[24]}$. Hu et al. ${ }^{[33]}$ showed that EEP and WEP had significant inhibitory effects on IL-6 levels in rats with FCA-induced arthritis, but not on IFN- $\gamma$ and IL-2 levels. Others ${ }^{[5,56]}$ have reported that extracts from Chinese propolis suppressed mRNA and protein expression of IL-1 $\beta$ and IL- 6 induced by LPS in RAW264.7 cells. A decrease in TNF- $\alpha$ production in monocytes after LPS stimulation by Brazilian green propolis was described by Chan et al. ${ }^{[25]}$.
Results reported by Szliszka et al. ${ }^{[51]}$ suggested a crucial contribution of Brazilian green propolis in the modulation of chemokine-mediated inflammation. EEP-B downregulated the expression of MCP-1, MIP$1 \alpha$, MIP-1 $\beta$, and RANTES in LPS+IFN- $\gamma$ stimulated J774A. 1 cells. An ethanol extract of BRP at $10 \mathrm{mg} / \mathrm{kg}$ downregulated the expression of TNF- $\alpha$. This was linked to neutrophils transmigration and IL-1 $\beta$, which increased inflammatory cells recruitment in various inflammatory models, including the peritoneal cavity ${ }^{[57]}$. Bueno-Silva et al..$^{[57]}$ have also suggested that BRP inhibition of neutrophil migration might be linked to a reduction in CXCL1/KC and CXCL2/ MIP-2 release and consequently a decrease in neutrophil chemotaxis, as well as bearing, adhesion and transmigration into the inflammatory focus. The researchers identified formononetin from BRP as the major compound, present in the amount of $24.45 \mathrm{mg} / \mathrm{g}$. In addition, daidzein and biochanin A were identified as minor compounds. Another EEP $(1 \mu \mathrm{g} / \mathrm{ml})$ mechanism observed in this study was the direct blockage of calcium influx in neutrophils, which in turn decreased neutrophil chemotaxis, since calcium is necessary for chemotaxis. The study suggested that propolis and its components (CAPE) are potent and specific inhibitors of NF- $\kappa \mathrm{B}$ activation. CAPE not only inhibited transcription factors, but also reduced production of IL-8 (a cytokine that increases neutrophil chemotaxis) and monocyte chemotactic protein (MCP) ${ }^{[58]}$.

\section{Immunomodulatory effects on the function of $T$ and B lymphocytes:}

$\mathrm{T}$ and $\mathrm{B}$ cells are another major population of peripheral blood mononuclear cells (PBMC), which play an important role in adaptive immune defence. These cells' ability to distinguish self from nonself allows them to clear exogenous antigens. In this manner the immune system plays a pivotal role in the human body's defence against infection. Numerous harmful influences of endogenous or exogenous origin cause pathological alterations in the human body. The immune system is activated by these stimuli and switches on various molecular mechanisms of innate and adaptive immunity. Individual types of antigens bind and activate different populations of $\mathrm{T}$ cells and/or B cells, which have different immune functions. Previously, however, inside macrophages, bacteria will be phagocytized and then recognized by major histocompatibility complex II (MHC II) and presented in the form of peptide antigen. Furthermore, 
MHC II binds to $\mathrm{T}$ lymphocytes. T lymphocytes are known to have several surface molecules or clusters of differentiation (CD). Antigen peptides that have been presented by MHC II bind to T helper lymphocytes (CD4) on the T cell receptor (TCR). Ligands between the antigen-MHC complex with TCR-CD3 activate inositol triphosphate and glycerol compounds in the $\mathrm{T}$ cell membrane. Inositol triphosphate will increase calcium ion in the cytoplasm, whereas diacylglycerol activates the enzyme protein kinase-C. Both are a signal to activate $\mathrm{T}$ cells ${ }^{[59]}$.

The activation of Tymphocytes leads to the expression of cytokine genes. Cytokines bound to specific receptors on the surface of target cells regulate the growth or/ and differentiation of the cells and thus optimize the immune response. The development of humoral and cellular immunity depends on cytokine production mainly by $\mathrm{CD}^{+}$cells $^{[60]}$. For examples, type I helper T cells produce IL- 2 and IFN- $\gamma$ to activate CD8 cytotoxic $\mathrm{T}$ cells ${ }^{[61]}$ and type II helper T cells secrete IL-4, IL-5, IL-6 and IL-13 to facilitate activation of B cells ${ }^{[62]}$.

The immunomodulatory effect of propolis in resting human PBMC is mainly due to their action on monocytes. However, T and B lymphocytes are another major component of PBMC that may be affected by propolis. Some authors have shown that propolis stimulates lymphocyte proliferation, while others, claim that propolis and its components, especially flavonoids are active immunosuppressants that inhibit lymphocyte proliferation. In fact both statements are correct, but the effect of propolis depends on its concentration. Marquez et al. ${ }^{[17]}$ have evaluated the immunosuppressive activity of CAPE in human T cells, discovering that this phenolic compound is a potent inhibitor of early and late events in receptor-mediated $\mathrm{T}$ cell activation. Moreover, they found that CAPE at a concentration of $10 \mu \mathrm{M}$ specifically inhibited both IL-2 gene transcription and IL-2R (CD25) expression in stimulated human $\mathrm{T}$ cells. They proved that CAPE inhibited T-lymphocyte activation by targeting both NFAT and NF- $\kappa B$ transcription factors. Another explanation for the inhibitory effects of propolis on lymphoproliferation derives from observations by Ansorge et al. ${ }^{[63]}$. They studied the mitogen-activated protein (MAP) kinase signalling pathway, measuring the induction of mRNA expression of extracellularsignal-regulated kinase (Erk-2), which is capable of regulating several transcription factors. These in turn control the regulation of critical genes of lymphocytes, including the IL-2 gene. Erk-2 was strongly suppressed in propolis-stimulated $\mathrm{PBMC}$, which clearly suggests that one way of signalling triggered by propolis is mediated by MAP kinase Erk-2.

Draganova-Filipova et al. ${ }^{[23]}$ studied the in vitro participation of Bulgarian propolis and CAPE in propolis in the modulation of both cellular and humoral immunity (Table 2). The percentages of $\mathrm{T}$ helper (h)/inducer (i) $\left(\mathrm{CD}^{+} \mathrm{CD}^{+}\right), \quad \mathrm{T}$ cytotoxic (c) $\left(\mathrm{CD}^{+} \mathrm{CD}^{+}\right)$and $\mathrm{B}\left(\mathrm{CD} 19^{+} \mathrm{CD} 3^{-}\right)$lymphocyte subsets were determined by flow cytometry after cultivation with EEP and CAPE at different concentrations. The low concentration of propolis had a stimulating effect on the $\mathrm{T}$ cell immune response. On the other hand, the positive effect of the low concentration on B-lymphocytes determined its potential to stimulate antibody production. The highest propolis concentration $(10 \mathrm{mg} / \mathrm{l})$ had a toxic effect and caused cell death. After CAPE treatment of the cells the tendencies observed were similar to those determined after propolis treatment, but the effect was more intense. The results might be explained by the fact that CAPE was a chemically synthesized product and had a stronger effect at a lower concentration than the complex product.

Similarly, an inhibitory effect of propolis $(5-100 \mathrm{mg} / \mathrm{ml})$ on splenocyte proliferation was observed in vitro in a study by Sá-Nunes et al. ${ }^{[64]}$. Park et al. ${ }^{[65]}$ have also reported that treatment with CAPE directly or indirectly causes immune cells to decrease in number, especially T cells.

Previous research by Draganova-Filipova et al. ${ }^{[23]}$ found that propolis-treated PBMC had the ability to produce IL-2. The stimulating effect of IL-2 was probably directed to $\mathrm{T}$ cells. The authors supposed that as a result of intermolecular interactions propolis activates Th cells and stimulates cellular and humoral immunity in vitro. The same authors ${ }^{[23]}$ demonstrated that the alteration in expression of CD69 (a cell surface protein synthesized rapidly about two hours after activation) after CAPE treatment was greater in $\mathrm{CD}^{+} / \mathrm{CD} 69^{+}$cells than $\mathrm{CD} 8^{+} / \mathrm{CD} 69^{+}$cells. The effect was more pronounced at the lowest concentration, i.e. $2 \mathrm{mg} / 1$.

In vivo experiments have demonstrated that propolis stimulated $\mathrm{T}$ lymphocyte proliferation and the secretion of IL-2, IL-4 and IFN- $\gamma$ in Balb/c mice, but had no effect on B lymphocyte blastogenesis induced by lipopolysaccharide. This led to a decrease in their number in relation to the total number of 
www.ijpsonline.com

TABLE 2: EFFECT OF PROPOLIS ON LYMPHOCYTES ACTIVITY

\begin{tabular}{|c|c|c|c|c|c|}
\hline Immunological assay & Effect & Propolis dose & In vivo/in vitro & $\begin{array}{l}\text { Main groups or active } \\
\text { components }\end{array}$ & Reference \\
\hline \multirow{2}{*}{$\begin{array}{l}\text { Proliferation of B } \\
\text { cells }\end{array}$} & ${ }^{1} \uparrow$ & $0.01 ; 1 ; 2.5 ; 5 \mathrm{mg} / \mathrm{l}$ & In vitro & \multirow{2}{*}{$\begin{array}{c}\text { Phenolic acids, aromatic esters } \\
\text { (CAPE), flavonoids (chrysin, } \\
\text { pinocembrin, galangin) }\end{array}$} & \multirow[t]{2}{*}{23} \\
\hline & ${ }^{3} \downarrow$ & $10 \mathrm{mg} / \mathrm{l}$ & ${ }^{2} \mathrm{PBMC}$ & & \\
\hline \multirow{4}{*}{ Production of IgG } & & & In vivo & \multirow{3}{*}{$\begin{array}{l}\text { Flavonoids, aliphatic acids, } \\
\text { aromatic acids, esters, alkohol, } \\
\text { terpene, kinons, benzene }\end{array}$} & \multirow{3}{*}{71} \\
\hline & $\uparrow$ & $3 \mathrm{~g} / \mathrm{kg}$ & $\begin{array}{l}\text { White Leghorn } \\
\text { laving hens }\end{array}$ & & \\
\hline & & & $\begin{array}{l}\text { laying hens } \\
\text { In vivo }\end{array}$ & & \\
\hline & $\uparrow$ & $157.4 \mathrm{mg} / \mathrm{kg}{ }^{4} \mathrm{bw}$ & $\begin{array}{l}\text { aged Kunning } \\
\text { mice } \\
\text { In vivo }\end{array}$ & $\begin{array}{l}\text { Polyphenols, flavonoids, } \\
\text { cinnamic acid, artepillin C }\end{array}$ & 24 \\
\hline \multirow{4}{*}{ Production of IgM } & $\uparrow$ & $3 \mathrm{~g} / \mathrm{kg}$ & & \multirow[t]{2}{*}{ As above } & \multirow[t]{2}{*}{71} \\
\hline & & & $\begin{array}{l}\text { As above } \\
\text { In vivo }\end{array}$ & & \\
\hline & No effect & $157.4 \mathrm{mg} / \mathrm{kg} \mathrm{bw}$ & & As above & 24 \\
\hline & & & $\begin{array}{l}\text { As above } \\
\text { In vivo }\end{array}$ & & \\
\hline \multirow{3}{*}{$\begin{array}{l}\text { T lymphocyte } \\
\text { proliferation }\end{array}$} & $\downarrow$ & $3 \mathrm{~g} / \mathrm{kg}$ & & As above & 71 \\
\hline & & & $\begin{array}{l}\text { As above } \\
\text { In vivo }\end{array}$ & & \\
\hline & $\uparrow$ & $157.4 \mathrm{mg} / \mathrm{kg}$ bw & As above & As above & 24 \\
\hline \multirow{2}{*}{$\begin{array}{l}\text { Proliferation of } \mathrm{T} \\
\text { helper/induce cells }\end{array}$} & $\uparrow$ & $0.01 ; 1 ; 2.5 ; 5 \mathrm{mg} / \mathrm{l}$ & & \multirow{4}{*}{ As above } & \multirow{4}{*}{23} \\
\hline & $\downarrow$ & $10 \mathrm{mg} / \mathrm{l}$ & In vitro & & \\
\hline Proliferation of $\mathrm{T}$ & $\uparrow$ & $0.01 ; 1 ; 2.5 ; 5 \mathrm{mg} / \mathrm{l}$ & As above & & \\
\hline cytotoxic cells & $\downarrow$ & $10 \mathrm{mg} / \mathrm{l}$ & & & \\
\hline
\end{tabular}

lymphocytes ${ }^{[65]}$. However, in other in vivo studies $10 \%$ propolis stimulated humoral immunity, causing antibody production in bovine serum albuminimmunized rats. Two propolis components used in this experiment, caffeic acid and quercetin, had no effect on antibody production, which can be explained by the synergetic effect of the propolis components as a whole ${ }^{[66]}$. Similarly, Kalsum et al. ${ }^{[36]}$ showed that extracts of propolis of Trigona sp. increase the potential of the humoral immune response as compared to rats that received antigen (bacteria Staphylococcus aureus) without propolis (negative control, $8.19 \mathrm{ng} / \mathrm{ml} \mathrm{IgG).}$ The content of serum IgG was increased significantly in rats that received $0.46 \%$ propolis of Trigona sp. (13.73 ng/ml IgG) as compared with other dosages of propolis $(0.16 \%-10.72 \mathrm{ng} / \mathrm{ml}$ and $1.44 \%-11.85 \mathrm{ng} / \mathrm{ml})$. Treatment with $0.46 \%$ propolis was not significantly different from that observed for CAPE (0.5\%$13.46 \mathrm{ng} / \mathrm{ml}$ - a positive control). Kalsum et al. ${ }^{[37]}$ considered the possibility that limonene, one of the most important constituents in propolis of Trigona sp. from Indonesia may play a role in increasing antibody production. Brazilian green propolis increased serum
IgG levels and SRBC-specific antibody production in aged mice receiving 83.3 and $157.4 \mathrm{mg} / \mathrm{kg}$ (34.48 \pm 5.94 and $32.35 \pm 9.08 \mathrm{~g} / \mathrm{l}$, respectively), as compared to control mice $(23.03 \pm 8.30 \mathrm{~g} / \mathrm{l})$, suggesting improved IgG production and an enhanced specific antibody response ${ }^{[24]}$. It is worth adding that aging is associated with a decline in B cell function and substantial impairment of the humoral response $\mathrm{e}^{[67]}$. The composition analysis indicated that the Brazilian green propolis used in this study was rich in polyphenols, flavonoids, cinnamic acid and artepillin C (189.12, $98.46,1.95$ and $23 \mathrm{mg} / \mathrm{g}$, respectively) ${ }^{[24]}$. Furthermore, Scheller et al. ${ }^{[68]}$ reported that an ethanol extract of propolis $(500 \mu \mathrm{g} /$ mouse $)$ increases antibody production in SRBC-immunized mice. However, a further increase in the propolis dose or in the frequency of its administration had an inhibitory effect on antibody production in immunized cells.

Similar results have been reported in laying hens and broiler chickens ${ }^{[69,70]}$. Results obtained by Cetin et al. ${ }^{[69]}$ showed that serum IgG and IgM levels (141.77 \pm 35.71 and $261.00 \pm 44.4 \mathrm{mg} / \mathrm{dl}$, respectively) in a group of laying hens receiving $3 \mathrm{~g} / \mathrm{kg}$ of Turkey propolis were 
significantly higher than in the control $(79.70 \pm 16.4$ and $172.65 \pm 29.2 \mathrm{mg} / \mathrm{dl}$, respectively), suggesting that $3 \mathrm{~g} / \mathrm{kg}$ of propolis could promote humoral immunity in birds. However, $6 \mathrm{~g} / \mathrm{kg}$ of propolis did not produce a significant elevation of the serum IgG and IgM level ( $98.50 \pm 28.27$ and $211.00 \pm 39.7 \mathrm{mg} / \mathrm{dl}$, respectively), which could be attributed to the main constituents of the Turkey propolis preparation such as benzene and flavonoids. Cetin's et al. ${ }^{[69]}$ findings were supported by Ziaren et al. ${ }^{[70]}$, who reported that humoral immunity was modulated by various levels of propolis in the diet of broilers. They observed that dietary propolis increased the antibody titre at low levels but decreased at high levels, thereby exhibiting a bell-shaped doseresponse relation.

A new line of research involving propolis involves its potential application as a vaccination adjuvant, although most commercial vaccines use aluminum salts to this end. A sample of green Brazilian propolis was tested, together with other adjuvant compounds, to immunize mice against inactivated swine herpesvirus. When administered together with aluminium hydroxide, the propolis extract increased both cellular and humoral responses ${ }^{[60]}$. According to Sforcin et al. ${ }^{[66]}$, the ability of propolis to modulate antibody synthesis is part of its adjuvant action. The immunostimulatory capacity of propolis, through increased immunoglobulin level has already been reported in patients with fibrosing alveolitis. Similarly, data presented by Fischer et al. ${ }^{[60]}$ showed that the use of an ethanol extract of green propolis can contribute to the efficacy of inactivated vaccines, acting as an immunostimulant. The ethanol extract of green propolis ( $40 \mathrm{mg} /$ dose) increased the potency of the humoral immune response in cattle when associated with an inactivated oil vaccine against bovine herpesvirus-type 5, showing adjuvant action. Phenolic compounds such as artepillin $\mathrm{C}$ and cinnamic acid derivatives, besides other flavonoid substances, were abundant in this propolis extract. These substances are known to have mitogenic action for B and T lymphocytes ${ }^{[22]}$.

Cheung et al. ${ }^{[71]}$ postulated that propolis and artepillin $\mathrm{C}$ could serve as a novel immunosuppressive drug for the treatment of graft-versus-host disease (GVHD). There is a delicate balance in the immune system so that immune defence does not target self-antigens. This self-preservation characteristic becomes a barrier during allogeneic bone marrow transplants. Unwanted $T$ cell activation in the recipient can lead to graft rejection. However, this response is always inhibited by the immunosuppressants targeted at treating GVHD. Hence, a good immunosuppressant for the treatment of GVHD should be able to inhibit $T$ cell activation and at the same time suppress cancer cells ${ }^{[66]}$.

Graft-versus-leukaemia is an important response to help eradicate leukaemia after haematopoietic stem cell transplantation. Propolis and artepillin $\mathrm{C}$ at concentrations that can suppress $\mathrm{T}$ cell proliferation showed a significant inhibitory effect on leukemic cell growth, especially for $\mathrm{T}$ lineage leukaemia, while having no effect on normal blood cells ${ }^{[56]}$.

Granzyme is a cytolytic enzyme produced cytotoxic $\mathrm{T}$ cells that play a role in lysing target cells, including cancer cells. Results of Kusnul et al.$^{[72]}$ showed that the increased level of $\mathrm{CD}^{+} \mathrm{T}$ cells-expressing granzyme and a decreased level in $\mathrm{CD}^{+} \mathrm{CD} 25^{+} \mathrm{T}$ cells-expressing granzyme by propolis extract were both provide positive benefits in cancer therapy.

\section{Immunomodulatory effects on the function of natural killer (NK) cells:}

NK cells are characterized as a lymphocyte subpopulation different from $\mathrm{T}$ and $\mathrm{B}$ cells, nonadherent and non-phagocytic, showing lytic activity mainly towards several types of tumour and virusinfected cells. NK cells are considered the host primary defence mechanism.

In vitro research has demonstrated that NK cells display considerably higher resistance to Bulgarian propolis in comparison with Th and Tc cells. Low concentrations of propolis $(0.01 ; 1 ; 2.5 ; 5 \mathrm{mg} / \mathrm{l})$ had a proliferative effect and almost no pro-apoptotic effect on NK cells. After CAPE treatment the resistance of NK cells was lower than after propolis treatment. At $4 \mathrm{mg} / \mathrm{l}$ of CAPE the vitality of NK cells decreased to $46.77 \%$. The $8 \mathrm{mg} / 1$ concentration increased the percentage of apoptotic NK cells, but the values were lower than those of the apoptotic $\mathrm{CD}^{+}$cells $-53.5 \%(\mathrm{Tc})$ and $61.48 \%(\mathrm{Th})^{[23]}$.

The effect of propolis on NK cells was investigated in vivo. Results reported by Sforcin et al..$^{[73]}$ indicated that NK activity was increased in spleen cells from propolis-treated rats. On the other hand, no effect was demonstrated on splenic NK cell activity in aged mice after treatment with Brazilian green propolis ${ }^{[24]}$.

Recent reports have suggested that the antitumour effects of propolis could be attributed to its modulatory effect on the immune system, which include macrophage activation; modulation of $\mathrm{B}$ and $\mathrm{T}$ lymphocytes and NK cells; antibody proliferation, and production of 
cytokines (IL-2, IL-10 and IFN- $\gamma$ ); downregulation of TLR-2 and human leukocyte antigen (HLA-DR) expression; induction of $\mathrm{H}_{2} \mathrm{O}_{2}$ release; inhibition of NO, PG and leukotriene generation; suppression of the lipoxygenase pathway of arachidonic acid metabolism and suppression of activity of myeloperoxidase, NADPH-oxidase, ornithine decarboxylase, tyrosineprotein-kinase, and hyaluronidase; and downregulation of transcription factors ${ }^{[74]}$.

Several authors have studied the antitumour properties of propolis and its chemical constituents, artepillin C, baccharin and drupanin, CAPE and chrysin in in vivo and in vitro models ${ }^{[75-78]}$. Resistance to spontaneous tumour development has been associated with the cytotoxic activity of NK cells, found both in humans and experimental animals. Scheller et al ${ }^{\left[{ }^{[79]}\right.}$ observed the cytotoxic effect of ethanol extract of propolis in micebearing Ehrlich carcinoma in vivo. The NK activity of non-adherent spleen cells was evaluated by the ${ }^{51} \mathrm{Cr}$ release cytotoxicity assay against murine lymphoma (Yac-1) target cells ${ }^{[72]}$. Furthermore, an inhibitory effect of aqueous and ethanol extracts of propolis on colon carcinogenesis was reported in rats ${ }^{[80,81]}$. Tripp et al. ${ }^{[82]}$ suggested that propolis-activated macrophages could produce cytokines such as TNF- $\alpha$ and IL-12, which act on NK cells, increasing their cytotoxic activity against tumour cells. The findings of Kimoto et al. ${ }^{[27]}$ indicated that artepillin $\mathrm{C}$ possesses direct antitumour activity. When artepillin $\mathrm{C}$ was applied to human and murine malignant tumour cells in vitro and in vivo, the growth of tumour cells was clearly inhibited. In addition to suppression of tumour growth, there was an increase in the ratio of CD4 to CD8 T cells and in the total number of helper cells.

\section{IMMUNOMODULATORY EFFECT OF PROPOLIS AND ITS COMPONENTS ON BASOPHILE/MASTOCYTE FUNCTION}

Basophiles are present in the peripheral blood in trace amounts, accounting for $0-1 \%$ of total white blood cells and mast cells are widely distributed throughout vascularized tissues and certain epithelia. Both types of cells play a major role in allergic diseases, such as asthma $^{[83]}$.

Sensitivity to individual antigens (allergens) depends on the production of $\mathrm{IgE}$ antibodies. This process requires the presence of $\mathrm{Th} 2$ cells to induce the switching of antigen-specific antibody classes produced by B lymphocytes and the production and secretion of IL-4 needed for the growth and differentiation of
B lymphocytes. IgE antibodies produced after prior contact with a specific antigen bind to $\mathrm{IgE}$ receptors on mast cells or basophils. Cross-linking of allergen with $\mathrm{IgE}$ and high affinity receptors (FceR) and calcium influx induces rapid cell degranulation and release of inflammatory mediators such as histamine, PGs, leukotrienes and platelet activating factor (PAF) and several proinflammatory and chemotactic cytokines, such as TNF- $\alpha$, interleukins IL-6, IL-8, IL-4, and IL-13, and transforming growth factor (TGF)- $\beta 1^{[84]}$.

The literature reported a few clinical studies on the antiallergic activity of propolis. Khayyala et al. ${ }^{\left[{ }^{[5]}\right.}$ administered an aqueous extract of $13 \%$ propolis daily for 2 mo to patients with mild-to-moderate asthma. The propolis-treated patients showed reduced incidence and severity of nocturnal attacks and improvement in ventilatory functions, which was associated with decreased PGs, leukotrienes, and proinflammatory cytokines such as TNF- $\alpha$, IL- 6 , and IL-8. The findings of Hirota et al. ${ }^{[86]}$ suggested that the ethanol extract of Brazilian green propolis could be potentially beneficial as a prophylactic and therapeutic agent for asthma. Ten percent propolis treatment ( $1 \mathrm{mg} / \mathrm{kg}$, once a day) inhibited the production of $\mathrm{IgE}$, representative Th-2 cytokines, chemokines MCP- 1 and TGF- $\beta 1$, allergenspecific IgE, which resulted in inhibition of AHR (airway hyper-responsiveness) and reduced collagen deposition and the influx of inflammatory cells into the lungs of BALB/c mice challenged with allergens such as Dermatophagoides farine and diesel exhaust particles. In an experimental study by Shinmei et al. ${ }^{[87]}$, propolis was given to rats for itchy nose and sneezing. The authors reported that symptoms were improved through decreased histamine release and that the longterm effects were favourable.

Likewise, Sy et al. ${ }^{[88]}$ and Ammar et al..$^{\left[{ }^{[8]}\right.}$ used a model of pulmonary inflammation induced by ovalbumin (OVA) and demonstrated that treatment with propolis inhibits pulmonary inflammation and decreases serum level of IgE. Results reported by Nagai et al. ${ }^{[90]}$ indicated that EEP modulates the proliferation of lung Th cells from Th2-cell-dominant to Th1-cell-dominant in an airway inflammation model of mice. This suggested that EEP has an effect on allergic asthma that developed in an IgE-dependent manner.

Ethanol and water extracts of Brazilian and Chinese propolis have been shown to possess antiallergic action, inhibiting histamine release in rat peritoneal mast cells induced by Compound 48/80 and Concanavalin $\mathrm{A}^{[91]}$. 
These results were in agreement with Nakamura's study evaluating the effects of Brazilian and Chinese propolis on $\beta$-hexosaminidase release from antigenstimulated rat basophilic leukaemia (RBL-2H3) cells. Both water and ethanol extracts of Chinese propolis inhibited degranulation more potently than Brazilian propolis extracts ${ }^{[92]}$.

Nakamura et al. ${ }^{[92]}$ identified chrysin and kaempferol as the major antiallergic components of ethanol extracts of Chinese propolis. Chrysin was also revealed to inhibit IL-4 and MCP-1 production by these cells. Park et al. ${ }^{[93]}$ showed that kaempferol suppressed elevation of intracellular calcium as well as histamine release from activated RBL-2H3 cells. Hirose et al. ${ }^{[94]}$ made an interesting suggestion of the involvement of haeme oxygenase-1 in inhibition of mast cell activation by kaempferol. CAPE, the main component of Chinese propolis extract, reportedly inhibited NF- $\kappa B$ activation and inhibited PAF release, thereby reducing anaphylaxis in mice with OVA-induced asthma ${ }^{[95]}$. Those findings were in agreement with those of Jung et $a l .{ }^{[96]}$, who found that caffeic acid phenethyl ester exerted inhibitory effects on the inflammatory cells in BAL fluid in a murine model of asthma. CAPE significantly decreased the total leukocyte, eosinophil, lymphocyte and macrophage counts. Mice treated with caffeic acid phenethyl ester also showed a marked reduction in the infiltration of inflammatory cells within the peribronchiolar and perivascular regions. Mirzoeva and Calder ${ }^{[4]}$ showed that propolis and CAPE were very potent inhibitors of $\mathrm{PG}$ and leukotriene synthesis by murine peritoneal macrophages in vitro and during zymosan-induced acute peritoneal inflammation in vivo. Orsi et al. ${ }^{[97]}$ demonstrated that propolis at higher concentrations $(300 \mathrm{mg} / \mathrm{ml})$ directly activated mast cells, promoting the release of inflammatory mediators, which could be linked to allergic processes in propolissensitive individuals.

Current in vitro and some preliminary in vivo data suggested that propolis has immunomodulatory and antiinflammatory properties. Propolis from different geographic locations might have different active constituents. CAPE is one of the major components of many varieties of propolis found in the temperate zone, while artepillin $\mathrm{C}$ is one of the major compounds uniquely found in Brazilian green propolis in the tropical region. Propolis and these components have been shown to have immunomodulatory effects on a wide spectrum of immune cells, including those of lymphoid or monocytic lineage. It exhibited an immunoregulatory effect on the basic functional properties of immune cells, which is mediated by the Erk2/MAP-kinase (extracellular signal-regulated kinase 2 and MAP-kinase) signalling pathway and eukaryotic transcription factors: NFAT and NF- $\kappa$ B. Some authors have shown that propolis activated immune cells, while others claimed that propolis and its components, especially flavonoids, were the active immunosuppressants. In fact both statements appear to be correct, but the effect of propolis depended on its concentration.

\section{REFERENCES}

1. Burdock GA. Review of the biological properties and toxicity of bee propolis (propolis). Food Chem Toxicol 1998;36:347-63.

2. Wolska K, Górska A, Adamiak A. Właściwości przeciwbakteryjne propolisu. Post Mirobiol 2016;55(4):343-50.

3. Bankova V. Chemical diversity of propolis and the problem of standardization. J Ethnopharmacol 2005;22:114-7.

4. Bankova VS, de Castro SL, Marcucci MC. Propolis: recent advances in chemistry and plant origin. Apidologie 2000;31:3-15.

5. Li F, Awale S, Tezuka Y, Esumi H, Kadota S. Study on the constituents of Mexican propolis and their cytotoxic activity against PANC-1 human pancreatic cancer cells. J Nat Prod 2010;73:623-7.

6. Ahn MR, Kumazawa S, Usui Y, Nakamura J, Matsuka $\mathrm{M}$, Zhu F, et al. Antioxidant activity and constituents of propolis collected in various areas of China. Food Chem 2007;101:1383-92.

7. Chen CN, Weng MS, Wu CL, Lin JK. Comparison of Radical Scavenging Activity, Cytotoxic Effects and Apoptosis Induction in Human Melanoma Cells by Taiwanese Propolis from Different Sources. Evid Based Complement Alternat Med 2004;1:175-85.

8. Huang WJ, Huang $\mathrm{CH}, \mathrm{Wu} \mathrm{CL}$, Lin JK, Chen YW, Lin CL, et al. Propolin G, a prenylflavanone, isolated from Taiwanese propolis, induces caspase-dependent apoptosis in brain cancer cells. J Agric Food Chem 2007;55:7366-76.

9. Markham KR, Mitchell KA, Wilkins AL, Daldy JA Yinrong L. HPLC and GC-MS identification of the major organic constituents in New Zealand propolis. Phytochemistry 1996;42:205-11.

10. Hegazi AG, Abd El Hady FK. Egyptian propolis: Antioxidant, antimicrobial activities and chemical composition of propolis from reclaimed lands. Z Naturforsch C 2002;57:395-402.

11. Popravko SA, Sokolov IV, Torgov IV. New natural phenolic triglycerides. Chem Nat Comp 1982;2:169-73.

12. Popravko SA, Sokolov MV. Plant sources of propolis. Pchelovodstvo 1980;2:28-9.

13. Righi AA, Negri G, Salatino A. Comparative chemistry of propolis from eight Brazilian localities. Evid Based Complement Alternat Med 2013;267878:14.

14. Park YK, Alencar SM, Aguiar CL. Botanical origin and chemical composition of Brazilian propolis. J Agric Food Chem 2002;50:2502-6. 
15. Teixeira EW, Message D, Negri G, Salatino A, Stringheta PC. Seasonal variation, chemical composition and antioxidant activity of Brazilian propolis samples. Evid Based Complement Alternat Med 2010;7(3):307-15.

16. Daugsch A, Moraes CS, Fort P, Yong K. Park. Brazilian red propolis - chemical composition and botanical origin. Evid Based Complement Alternat Med 2008;5(4):435-41.

17. Marquez N, Sancho R, Macho A, Calzado MA, Fiebich BL, Munoz E. Caffeic acid phenethyl ester inhibits T-cell activation by targeting both nuclear factor of activated T-cells and NFkappaB transcription factors. J Pharmacol Exp Ther 2004;308:993-1001.

18. Sforcin JM. Propolis and the immune system: a review. J Ethnopharmacol 2007;113:1-14.

19. Sforcin JM, Bankova V. Propolis: is there a potential for the development of new drugs? J Ethnopharmacol 2011;133(2):253-60.

20. Szliszka E, Król W. Polyphenols isolated from propolis augment TRAIL-induced apoptosis in cancer cells. Evid Based Complement Alternat Med 2013;2013:731940.

21. Yuan J, Liu J, Hu Y, Fan Y, Wang D, Guo L, et al. The immunological activity of propolis flavonoids liposome on the immune response against ND vaccine. Int J Biol Macromol 2012;51:400-5.

22. Havsteen BH. The biochemistry and medical significance of the flavonoids. Pharmacol Ther 2002;96(2-3):67-202.

23. Draganova-Filipova MN, Georgieva MG, Peycheva EN, Miloshev GA, Sarafian VS, Peychev LP. Effects of propolis and CAPE on proliferation and apoptosis of McCoy-Plovdiv cell line. Folia Med 2008;50:53-9.

24. Gao W, Wu J, Wei J, Pu L, Guo C, Yang J, et al. Brazilian green propolis improves immune function in aged mice. J Clin Biochem Nutr 2014;55(1):7-10.

25. Chan GC, Cheung KW, Sze DM. The immunomodulatory and anticancer properties of propolis. Clin Rev Allerg Immunol 2013;44:262-73.

26. de Castro PA, Savoldi M, Bonatto D, Barros MH, Goldman $\mathrm{MH}$, Berretta AA, et al. Molecular characterization of propolis induced cell death in Saccharomyces cerevisiae. Eukaryot Cell 2011;10:498-511.

27. Kimoto T, Arai S, Kohguchi M, Aga M, Nomura Y, Micallef $\mathrm{MJ}$, et al. Apoptosis and suppression of tumor growth by artepillin C extracted from Brazilian propolis. Cancer Detect Prev 1998;22:506-15.

28. Orsatti CL, Missima F, Pagliarone AC, Bachiega TF, Búfalo $\mathrm{MC}$, Araújo JP Jr, et al. Propolis immunomodulatory action in vivo on Toll-like receptors 2 and 4 expression and on proinflammatory cytokines production in mice. Phytother Res 2010;24:1141-6.

29. Edwards SW. Biochemistry and phisiology of the neutrophil. New York: Cambridgen University Press; 1994.

30. Aderem A, Underhill DM. Mechanisms of phagocytosis in macrophages. Annu Rev Immunol 1999;7:593-623.

31. Laskin DL, Pendino KJ. Macrophages and inflammatory mediators in tissue injury. Annu Rev Pharmacol Toxicol 1995;35:655-77.

32. Moonis M, Ahmad I, Bachhawat BK. Macrophage in host defense. An overview. Indian J Biochem Biophys 1992;29:115-22.

33. Scheller S, Tustanowski J, Felus E, Stojko A. Biological properties and clinical applications of propolis. VII.
Investigation of the influence of ethanol extract of propolis (EEP) on cartilaginous regeneration. Arzneimittelforschung 1977;27:2142.

34. Orsi RO, Funari SRC, Soares AMVC, Calvi SA, Oliveira SL, Sforcin JM, et al. Immunomodulatory action of propolis on macrophage activation. J Venom Anim Toxins Incl Trop Dis 2000;6:205-19.

35. Orsi RO, Sforcin JM, Funari SRC, Bankova V. Effects of Brazilian and Bulgarian propolis on bactericidal activity of macrophages against Salmonella typhimurium. Int Immunopharmacol 2005;5:359-68.

36. Kalsum N, Sulaeman A, Setiawan B, Wibawan IWT. Preliminary studies of the immunomodulator effect of the propolis Trigona spp. extract in a mouse model. J Agrc Vet Sci 2017;10(2):75-80.

37. Kalsum N, Sulaeman A, Setiawan B, Wibawan IWT. Phytochemical profiles of propolis Trigona spp. from three regions in Indonesia using GC-MS. J Biol Agric Health 2016;6(14):31-7.

38. Possamai MM, Honorio-França AC, Reinaque AP, França EL, Souto PC. Brazilian Propolis: A natural product that improved the fungicidal activity by blood phagocytes. Biomed Res Int 2013;541018:9.

39. Murad JM, Calvi SA, Soares AMVC, Bankova V, Sforcin JM. Effects of propolis from Brazil and Bulgaria on fungicidal activity of macrophages against Paracoccidioides brasiliensis. J Ethnopharmacol 2002;79:331-4.

40. Dantas AP, Olivieri BP, Gomes FHM, De Castro SL. Treatment of Trypanosoma cruzi-infected mice with propolis promotes changes in the immune response. J Ethnopharmacol 2006;103:187-93.

41. Syamsudin, Dewi RM, Kusmardi. Immunomodulatory and In vivo Antiplasmodial activities of propolis extracts. Am J Pharmacol Toxicol 2009;4(3):75-9.

42. Sampietro DA, Vattuone MMS, Vattuone MA. Immunomodulatory activity of Apis mellifera propolis from the North of Argentina. Food Sci Technol 2016;70:9-15.

43. Rindt JK, Spinu M, Niculae M, Szakacs B, Bianu G, Laslo L. The immunostimulatory activity of propolis from different origin. Vet Med Sci 2009;42(1):350-3.

44. Fischer G, Paulino N, Marcucci MC, Siedler BS, Munhoz LS, Finger PF, et al. Green propolis phenolic compounds act as vaccine adjuvants, improving humoral and cellular responses in mice inoculated with inactivated vaccines. Mem Inst Oswaldo Cruz 2010;105:908-13.

45. Król W, Czuba ZP, Pietsz G, Threadgill MD, Cunningham BD. Modulation of the cytotoxic activity of murine macrophages by flavones. Curr Top Biophys 1996;20:88-93.

46. Błońska M, Bronikowska J, Pietsz G, Czuba ZP, Scheller S, Krol W. Effects of ethanol extract of propolis (EEP) and its flavones on inducible gene expression in J774A.1 macrophages. J Ethnopharmacol 2004;91(1):25-30.

47. Simôes LMC, Gregório LE, Da Silva Filho AA, de Souza ML, Azzolini AE, Bastos JK, et al. Effect of Brazilian green propolis on the production of reactive oxygen species by stimulated neutrophils. J Ethnopharmacol 2004;94(1):59-65.

48. Simôes-Ambrosio LMC, Gregório LE, Sousa JPB, FigueiredoRinhel AS, Azzolini AE, Bastos JK, et al. The role of seasonality on the inhibitory effect of Brazilian green propolis on the oxidative metabolism of neutrophils. Fitoterapia 2010;81(8):1102-8. 
49. Socha R, Gałkowska D, Bugaj M, Juszczak L. Phenolic composition and antioxidant activity of propolis from various regions of Poland. Nat Prod Res 2015;29(5):416-22.

50. Izuta H, Narahara Y, Shimazawa M, Mishima S, Kondo SI, Hara H. 1,1-diphenyl-2-picrylhydrazyl radical scavenging activity of bee products and their constituents determined by ESR. Biol Pharm Bull 2009;32(12):1947-51.

51. Szliszka E, Kucharska AZ, Sokół-Łętowska B, Mertas A, Czuba ZP, Król W. Chemical Composition and AntiInflammatory. Effect of ethanolic extract of Brazilian green propolis on activated J774A.1 macrophages. Evid Based Complement Alternat Med 2013;2013:976415.

52. Paulino N, Abreu SRL, Uto Y, Koyama D, Nagasawa H, Hori $\mathrm{H}$, et al. Anti-inflammatory effects of a bioavailable compound, Artepillin C, in Brazilian propolis. Eur J Pharmacol 2008;587(1-3):296-301.

53. Hu F, Hepburn HR, Li Y, Chen M, Radloff SE, Daya S. Effects of ethanol and water extracts of propolis (bee glue) on acute inflammatory animal models. J Ethnopharmacol 2005;100:276-83.

54. Mirzoeva OK, Calder PC. The effect of propolis and its components on eicosanoid production during the inflammatory response. Prostaglandins Leukot Essent Fatty Acids 1996;55(6):441-9.

55. Shi $H$, Yang $H$, Zhang $X$, Yu LL. Identification and quantification of phytochemical composition and anti-inflammatory and radical scavenging properties of methanolic extract of Chinese propolis. J Agric Food Chem 2012;60:12403-10.

56. Wang $\mathrm{K}$, Ping S, Huang S, Hu L, Xuan H, Zhang C, et al. Molecular mechanisms underlying the in vitro antiinflammatory effects of flavonoid-rich ethanol extract from Chinese propolis. Evid Based Complement Alternat Med 2013;127672:11.

57. Bueno-Silva B, Franchin M, Alves CF, Denny C, Colón DF, Cunha TM, et al. Main pathways of action of Brazilian red propolis on the modulation of neutrophils migration in the inflammatory proces. Phytomedicine 2016;23:1583-90.

58. Lee KW, Chun KS, Lee JS, Kang KS, Surh YJ, Lee HJ. Inhibition of cyclooxygenase-2 expression and restoration of gap junction intercellular communication in H-rastransformed rat liver epithelial cells by caffeic acid phenethyl ester. Ann N Y Acad Sci 2004;1030:501-7.

59. Foulds KE, Zenewicz LA, Shedlock DJ, Jiang J, Troy AE, Shen H. Cutting edge: CD4 and CD8 T cells are intrinsically different in their proliferative responses. $\mathrm{J}$ Immunol 2002;15(4):1528-32.

60. Fischer G, Conceição FR, Leite FP, Dummer LA, Vargas GD, Hübner Sde $\mathrm{O}$, et al. Immunomodulation produced by green propolis extract on humoral and cellular responses of mice immunized with SuHV-1. Vaccine 2007;25:1250-6.

61. Lai YP, Lin CC, Liao WJ, Tang CY, Chen S.C. CD4+ T cellderived IL-2 signals during early priming advances primary CD8+ T cell responses. PLoS One 2009;4:e7766.

62. Kashiwada M, Levy DM, McKeag L, Murray K, Schroder AJ, Canfield SM, et al. IL-4-induced transcription factor NFIL3/ E4BP4 controls IgE class switching. Proc Natl Acad Sci USA 2010;107:821-6.

63. Ansorge S, Reinhold D, Lendeckel U. Propolis and some of its constituents down-regulate DNA synthesis and inflammatory cytokine production but induce TGF-betal production of human immune cells. Z Naturforsch C 2003;58:580-9.

64. Sá-Nunes A, Faccioli LH, Sforcin JM. Propolis: lymphocyte proliferation and IFN- production. J Ethnopharmacol 2003;87:93-7.

65. Park JH, Lee JK, Kim HS, Chung ST, Eom JH, Kim KA, et al. Immunomodulatory effect of caffeic acid phenethyl ester in Balb/c mice. Int Immunopharmacol 2004;4:429-36.

66. Sforcin JM, Orsi OR, Bankova VJ. Effects of propolis, some isolated compounds and its source plant on antibody production. J Ethnopharmacol 2015;98:301-5.

67. Frasca D, Riley RL, Blomberg BB. Humoral immune response and B-cell functions including immunoglobulin class switch are downregulated in aged mice and humans. Semin Immunol 2005;17:378-84.

68. Scheller S, Gazda G, Pietsz G, Gabrys J, Szumlas J, Eckert $\mathrm{L}$, et al. The ability of ethanol extract of propolis to stimulate plaque formationin immunized mouse spleen cells. Pharmacol Res Commun 1988;20:323-8.

69. Cetin E, Silici S, Cetin N, Güçlü BK. Effects of diets containing different concentrations of propolis on hematological and immunological variables in laying hens. Poult Sci 2010;89:1703-8.

70. Ziaren HR, Rahmani HR, Pourreza J. Effect of dietary oil extract of propolis on immune response and broiler performance. Pakistan J Biol Sci 2005;8:1485-90.

71. Cheung KW, Sze DM, Chan WK, Deng RX, Tu W, Chan GC. Brazilian green propolis and its constituent, artepillin C inhibits allogeneic activated human CD4 T cells expansion and activation. J Ethnopharmacol 2011;38:463-71.

72. KusnulZ, RahayuP, Rifai M, Widjajanto E. Immunomodulatory effect of propolis on granzyme expression in $\mathrm{CD} 8+$ and CD4+CD25+ T cells. Turk J Immunol 2017;5(1):13-9.

73. Sforcin JM, Kaneno R, Funari SRC. Absence of seasonal effect on the immunomodulatory action of Brazilian propolis on natural killer activity. J Venom Anim Toxins 2002;8(1):54.

74. Chirumbolo S. Anti-inflammatory property of propolis. J Clin Biochem Nutr 2015;56:163-4.

75. Kimoto T, Koya-Miyata S, Hino K, Micallef MJ, Hanaya T, Arai $\mathrm{S}$, et al. Pulmonary carcinogenesis induced by ferric nitrilotriacetate in mice and protection from it by Brazilian propolis and artepillin C. Virchows Arch 2001;438:259-70.

76. Li X, Wang JN, Huang JM, Xiong XK, Chen MF, Ong CN, et al. Chrysin promotes tumor necrosis factor (TNF)-related apoptosis-inducing ligand (TRAIL) induced apoptosis in human cancer cell lines. Toxicol In Vitro 2011;25:630-5.

77. Mishima S, Ono Y, Araki Y, Akao Y, Nozawa Y. Two related cinnamic Acid derivatives from Brazilian honey bee propolis, baccharin and drupanin, induce growth inhibition in allografted sarcoma S-180 in mice. Biol Pharm Bull 2005;28:1025-30.

78. Orsolic N, Basic I. Antitumor, hematostimulative and radioprotective action of water-soluble derivative of propolis (WSDP). Biomed Pharmacother 2005;59:561-70.

79. Scheller S, Krol W, Swiacik J, Owczarek S, Gabrys J, Shani J. Antitumoral property of ethanolic extract of propolis in mice-bearing Ehrlich carcinoma, as compared to bleomycin. Z Naturforsch C 1989;44(11-12):1063-5.

80. Yasui Y, Miyamoto S, Kim M, Kohno H, Sugie S, Tanaka T. Aqueous and ethanolic extract fractions from the Brazilian propolis suppress azoxymethane-induced aberrant crypt foci in rats. Oncol Rep 2008;20:493-9.

81. Borrelli F, Izzo AA, Di Carlo G, Maffia P, Russo A, Maiello FM, et al. Effect of a propolis extract and caffeic acid 
phenethyl ester on formation of aberrant crypt foci and tumors in the rat colon. Fitoterapia 2002;73(Suppl 1):S38-43.

82. Tripp CS, Wolf SF, Unanue ER. Interleukin 12 and tumor necrosis factor alpha are costimulators of interferon gamma production by natural killer cells in severe combined immunodeficiency mice with listeriosis, and interleukin 10 is a physiologic antagonist. Proc Natl Acad Sci U S A 1993;90(8):3725-9.

83. Wershil BK, Galli SJ. The analysis of mast cell function in vivo using mast cell-deficient mice. Adv Exp Med Biol 1994;347:39-54.

84. Galli SJ, Kalesnikoff J, Grimbaldeston MA, Piliponsky AM, Williams CM, Tsai M. Mast cells as 'tunable' effector and immunoregulatory cells: recent advances. Annu Rev Immunol 2005;23:749-86.

85. Khayyala MT, el-Ghazalyb MA, El-Khatiba AS, Hatemc AM, de Vriesd PJF, El-Shafeic S, et al. A clinical pharmacological study of the potential beneficial effects of a propolis food product as an adjuvant in asthmatic patients. Fundam Clin Pharmacol 2003;17:93-102.

86. Hirota R, Ngatui NR, Nakamura H, Suganuma N. Propolis inhalation reduces allergic airway inflammation in Dermatophagoides farinae -treated Mice. International Conference on Nutrition and Food Sciences IPCBEE. Vol. 39. Singapore: IACSIT Press; 2012.

87. Shinmei Y, Kagawa Y, Yano H, Hossen MA, Kamei C. Effect of topical application of Brazilian propolis on scratching behaviour induced by Compound 48/80 in mice. Immunopharmacol Immunotoxicol 2010;32(2):327-32.

88. Sy LB, Wu YL, Chiang BL, Wang YH, Wu WM. Propolis extracts exhibit an immunoregulatory activity in an OVA-sensitized airway inflammatory animal model. Int Immunopharmacol 2006;6(7):1053-60.

89. Ammar E-SM, Gameil NM, Nader MA, Shawky NM. Chinese propolis attenuates in vivo and in vitro asthmatic reactions. J Aller Ther 2013;S11:006.

90. Nagai T, Inoue R. Preparation and the functional properties of water extract and alkaline extract of royal jelly. Food Chem 2004;84:181-6.

91. Miyataka H, Nishiki M, Matsumoto H, Fujimoto T, Matsuka $\mathrm{M}$, Isobe A, et al. Evaluation of propolis (II): effects of Brazilian and Chinese propolis on histaminę release from rat peritoneal mast cells induced by compound 48/80 and concanavalin A. Biol Pharm Bull 1998;21(7):723-9.

92. Nakamura R, Watanabe K, Oka K, Ohta S, Mishima S. Effects of propolis from different areas on mast cell degranulation and identification of the effective components in propolis. Int Immunopharmacol 2010;10:1107-12.

93. Park HH, Lee S, Son HY, Park SB, Kim MS, Choi EJ, et al. Flavonoids inhibit histamine release and expression of proinflammatory cytokines in mast cells. Arch Pharm Res 2008;31:1303-11.

94. Hirose E, Matsushima M, Takagi K, Ota Y, Ishigami K, Hirayama $\mathrm{T}$, et al. Involvement of heme oxygenase- 1 in kaempferol-induced anti-allergic actions in RBL-2H3 cells. Inflammation 2009;32:99-108.

95. Park SG, Lee DY, Seo S, Lee SW, Kim SK, Jung WK, et al. Evaluation of anti-allergic properties of caffeic acid phenethyl ester in a murine model of systemic anaphylaxis. Toxicol Appl Pharmacol 2008;226(1):22-9.

96. Jung WK, Lee DY, Choi YH, Yea SS, Choi I, Park SG, et al. Caffeic acid phenethyl ester attenuates allergic airway inflammation and hyperresponsiveness in murine model of ovalbumin-induced asthma. Life Sci 2008;82:797-805.

97. Orsi RO, Sforcin JM, Funari SRC, Gomes JC. Effect of propolis extract on quinea pig lung mast cell. J Venom Anim Toxins Incl Trop Dis 2005;11(1):76-83. 